\title{
Empirical Support for the Use of Prescribed Burning as a Fuel Treatment
}

\author{
Paulo M. Fernandes ${ }^{1}$
}

Published online: 31 March 2015

(C) Springer International Publishing AG 2015

\begin{abstract}
Prescribed burning as a fuel treatment seeks to moderate wildfire impacts and decreases the areal extent of wildfires by increasing the effectiveness of fire suppression. Assessment of prescribed burning effectiveness is frequently anecdotal or based on simulation. This paper examines recent observational evidence of prescribed fire effectiveness. The spread rate and intensity of experimental fires in distinct fuel types have been shown to increase with time since treatment (fuel age) following fuel structure recovery. Prescribed fire constrains the size and especially the severity of individual fires, even under extremely severe weather conditions. At larger spatial and temporal scales of analysis, the effect of fuel age on unplanned fire severity is also evident, whether it comes from wildfires entering treated areas or from wildfires in fuel-reduced areas resulting from earlier wildfire occurrences. The persistence of these effects is variable, depending on vegetation type and productivity. The long-term reduction in wildfire area brought about by prescribed fire can be difficult to ascertain. Substantial effort (annual treatment rates $>5 \%$ of the landscape) has been shown to effectively control the extent of wildfires in forests, with 3-4 units of prescribed burning needed to reduce wildfire by one unit. Future studies should consider the decrease in area burned by high-severity fire as a more meaningful and objective measure of prescribed
\end{abstract}

This article is part of the Topical Collection on Fire Science and Management

Paulo M. Fernandes pfern@utad.pt

1 Centro de Investigação e de Tecnologias Agro-Ambientais e Tecnológicas (CITAB), Departamento de Ciências Florestais e Arquitetura Paisagista, Universidade de Trás-os-Montes e Alto Douro, Quinta de Prados, 5000-801 Vila Real, Portugal fire effectiveness than the decrease in wildfire area and should strive to document fire behaviour in treated versus untreated areas during wildfires.

Keywords Fire management · Fire behaviour · Fire hazard reduction $\cdot$ Fire regime $\cdot$ Fire severity $\cdot$ Fire use

\section{Introduction}

Wildland fire is an intrinsic component of terrestrial ecosystems where vegetation exists in sufficient amount and continuity to burn whenever warranted by weather conditions. While the pervasive nature and ecological role of fire excludes its eradication, fire management activities attempt to regulate the fire regime to minimize the potential negative impacts of fire and optimize its benefits for both ecosystems and human communities. The tendency to allocate most of the fire management investment to the suppression of unwanted fires can paradoxically exacerbate the problem, as fuels accumulate to levels that preclude effective fire-fighting operations regardless of the resources available, which has been described as the 'fire-fighting trap' [1]. Managing vegetation fuels is the sole option available to fire managers to modify fire behaviour characteristics, simply because the other influences (weather and topography) are beyond human control.

Fuels treatments reduce fuel loading or modify fuel structure such that rates of fire spread and fuel available for combustion are substantially reduced, thus diminishing resultant fireline intensities and improving the likelihood of fire containment and extinction, lowering damages and leading to smaller fire sizes (Fig. 1) [2-4]. Prescribed burning (PB) is the planned, controlled and exact (i.e. following a predefined prescription) use of fire to attain specific and well-defined resource management goals, according to state-of-the-art fire 
Fig. 1 Potential effects of prescribed burning as a fuel treatment. Arrows denote mitigation of fire behaviour and effects and the corresponding impacts on fire suppression and the fire regime. The benefits are not universal across vegetation types (e.g. frequent PB can favour grassy fuels thus increasing fire spread rates)

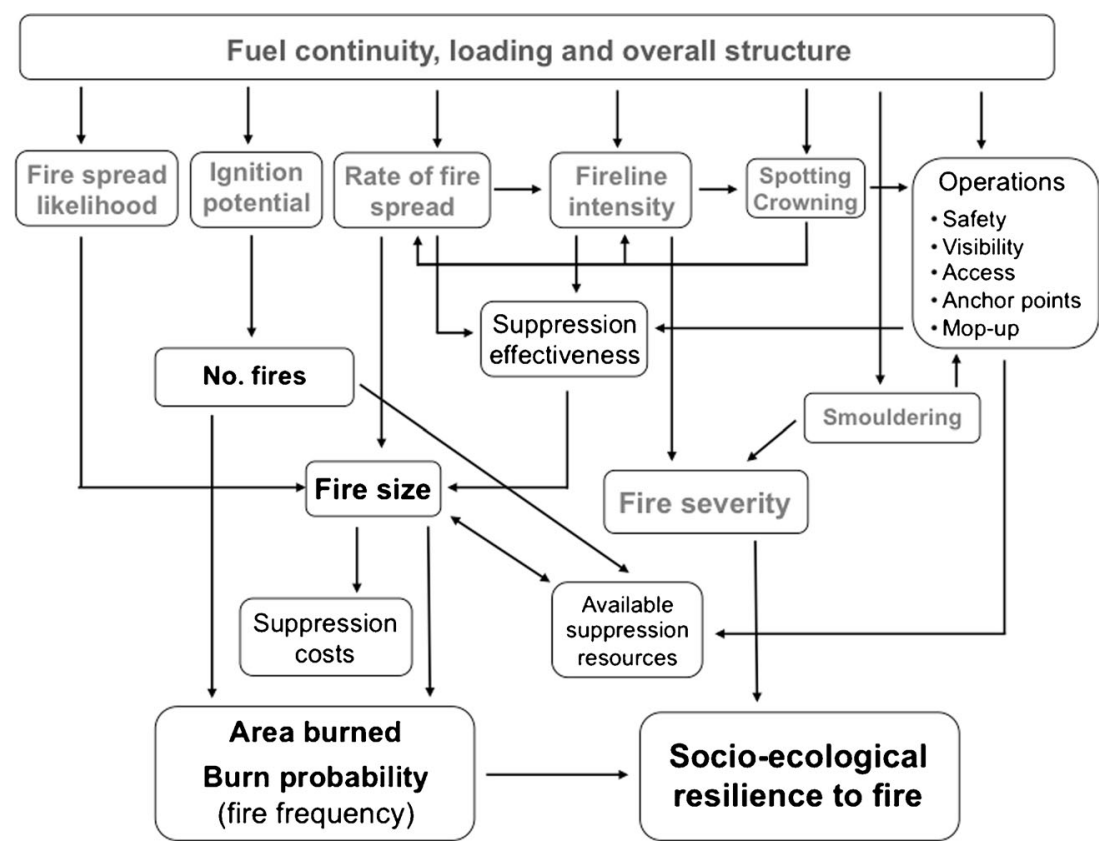

behaviour and fire ecology knowledge [5]. PB often is the preferred fuel treatment due to economic and effectiveness considerations. By increasing frequency of application and reflecting distinct constraints and challenges, $\mathrm{PB}$ is practiced in a wide diversity of vegetation types in Europe [6], South Africa [7], North America [8] and Australia [3, 9, 10]. The success of a PB programme is conditional on the existence of a knowledgeable, experienced and flexible staff, institutional compliance with adaptive management and engagement with society [3].

Fuel treatment effectiveness, including PB, varies with vegetation and treatment type [11]. PB is stand replacing in open, single-layered vegetation types (i.e. it removes the grass or shrub layer); fireline intensity can be exceedingly high but unburnt patches typically remain. Forests have at least two fuel layers, and PB is usually practiced as an understory low-intensity fire that consumes grasses, shrubs and the litter and woody fuels that comprise the forest floor and surface fuel (Fig. 2). A pruning/thinning effect is also possible depending on tree size and the fireline intensity, further decreasing the likelihood of subsequent crown fire development. This highlights a fundamental difference between PB in grassland or shrubland and in certain forest types, where in practical terms, the treatment effect will persist as long as crowning is avoided.

The fuel reduction effectiveness of a given PB operation is defined by the extent to which fuels are consumed and is dependent on their moisture, amount, particle dimensions, location in the fuel profile and overall fuel complex structure [12-16]. The rate of fuel recovery (e.g. [17]) in turn defines the longevity of the treatment effect. Several approaches can be taken to assess and quantify PB effectiveness, including the immediate treatment impacts on the fuel complex, observation of fire behaviour and effects associated with experimental fires, prescribed fires and wildfires, fire behaviour simulation at various spatial and temporal scales and modification of the fire regime [2]. Changes in wildfire severity (crown scorch metrics, tree mortality), assessed on-the-ground or remotely, are widely used to gauge the effectiveness of PB [11].

Literature on fuel treatment effectiveness has undergone substantial additions in the last few years, but 'anecdote,

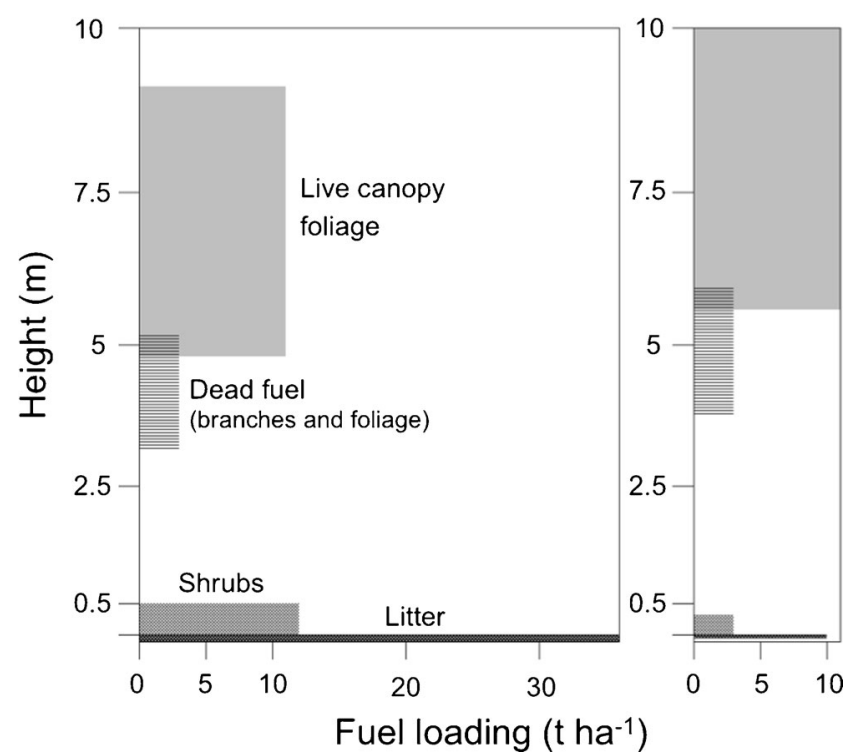

Fig. 2 Effect of prescribed burning on fuel stratification and loading in a 28-year-old maritime pine (Pinus pinaster) stand, North-Eastern Portugal: untreated (left) versus prescribed burnt at ages of 14 and 25 years $($ right). Fuel accumulation in the treated situation is four times lower, and the canopy distance to the ground is higher, making the transition of surface to crown fire more difficult. Adapted from [18] 
theory and modelling' [11] are still prevalent. This review updates the state-of-the-art on PB effectiveness but excludes studies that have used semi-empirical fire modelling systems, namely because of incorrect model linkages and underprediction bias [19], and output susceptibility to the assumptions used [20]. PB effectiveness inferred from fire modelling can oppose experimental results [21] and is optimistic in comparison with the findings of landscape scale empirical analysis [22]. We also ignored studies of post-treatment dynamics of fuel loading and structure that lacked companion fire behaviour data. Only PB (and PB plus thinning) treatments and programmes tested by fire, either experimental or unplanned, are considered here, along with inferences from research on the impact of past fire on wildfire size, extent and severity.

\section{Experimentation on the Role of Fuel Structure in Fire Behaviour}

Observations and measurement during experimental fires and the empirically based models developed with those data are the benchmark to assess the efficacy of fuel treatments at the plot or stand scale. Variation in fuel complex characteristics and the range in other environmental conditions (weather, terrain) affect the results. Practical and risk considerations usually preclude experimental fire behaviour studies under extreme fire weather. Nevertheless, model extrapolation has been deemed acceptable, provided that the functional relationships in the models are robust [23, 24]. Identification, let alone quantification of the effects of structural fuel properties on fire behaviour characteristics is difficult from field data, namely because of unavoidable correlation between putative independent variables (e.g. [17]) and the dominating influence (and usually larger experimental variation) of wind speed and fuel moisture.

Litter depth or vegetation height is visually apparent descriptors of fuel accumulation and to a certain extent should correlate with fuel age (time since treatment). Recent empirically based models for fire spread rate account for the effect of fuel structure through fuel depth or height, namely in semiarid shrubland [25], oceanic-climate shrubland [26], shrubland in general [27] and Mediterranean pine forest [28]. For the latter, the effect of fuel recovery (translated as time since PB) on simulated fire behaviour indicates that it is fireline intensity rather than rate of spread that reflects treatment persistence (Fig. 3). Flame length, but not rate of spread, differed between experimental fires in 10- and 25-year-old fuel complexes in a maritime pine stand after considering the effects of other variables [21]. By definition, and disregarding the comparatively minor effect of fuel moisture on heat of combustion, fireline intensity in a given fuel type increases linearly with the product of rate of spread and available fuel loading.

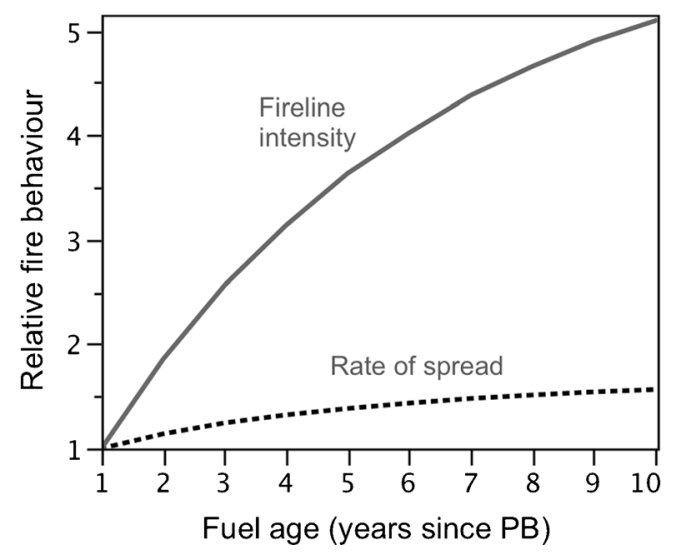

Fig. 3 The effect of fuel age on normalized surface fire behaviour characteristics in NW Portugal maritime pine stands with a low shrub understory as per the PiroPinus application [30]

Treatment longevity in maritime pine forest is then largely decided by post-treatment fuel build-up. In NW Spain heathland, fireline intensity during experimental fires was reduced by $78 \%$ in 3-year-old fuels in comparison with the untreated shrubland [29].

Project VESTA was the most extensive experimental burning programme in recent years. It was carried out in the dry eucalypt forests of South-Western Australia, during summer and under conditions of high fire danger [31•]. The experimental design was conceived to reveal and quantify the effect of varying fuel conditions ( 2 to 22 years after $\mathrm{PB}$ ) on fire behaviour characteristics. The existing fuel layers were characterized both quantitatively (load, height) and qualitatively, through hazard scores describing fuel structure and assigned visually. Surface (litter) and near-surface fuels did not change much after 6 years post-PB [17] and had the most effect on fire spread. The study found that some of the PB effect on fire behaviour, including spotting potential, persists until full recovery of pre-treatment understory fuel structure and bark hazard (i.e. up to 15-20 years after PB). Fuel hazard scores had higher predictive capacity than fuel loading and were integrated in equations to predict rate of spread and flame height, evaluated with data from additional experimental fires and wildfires [32].

\section{Prescribed Burning Effects on Fire Behaviour, Severity and Extent}

\section{Wildfire Case Studies}

Data from individual wildfires, especially those carefully monitored and well documented, tests PB effectiveness for the weather conditions inherent to the PB planning process and allow examination of the interaction between fuel reduction and fire suppression operations. High-intensity, fast- 
spreading and large wildfires are of particular interest for obvious reasons.

\section{Australia}

The Pickering Brook Fire in South-Western Australia burned 27,700 ha driven by winds of 16 to $31 \mathrm{~km} \mathrm{hr}^{-1}$ and dead fuel moisture contents between 4 and $9 \%$, with an average spread rate of $2 \mathrm{~km} \mathrm{hr}^{-1}$ during its most active phase [33]. The fire stopped by itself or was easily controlled in 1-2-year-old fuels resulting from $\mathrm{PB}$. Fire behaviour simulation indicated that the fire would have reached the wildland-urban interface in the absence of a PB programme, and its final size could have been three times higher. In the same region, but under more severe fire weather (air temperature $41^{\circ} \mathrm{C}$; relative humidity $12 \%$; wind speed $35 \mathrm{~km} \mathrm{hr}^{-1}$ ), 20- and 2-year-old fuels contrasted in the level of exhibited fire behaviour, respectively crown fire and low-intensity surface fire [3].

Several wildfires in Victoria burned nearly 0.5 million ha and killed 173 people on the 7th of February 2009 (termed 'Black Saturday'), of which the Kilmore East Fire was the most significant in many respects and has been studied in considerable detail [34]. Exceptionally, dry fuels and strong winds combined to produce fire behaviour in the far extreme of the spectrum, with rate of fire spread (impelled by shortrange spotting) and fireline intensity peaking at $9.2 \mathrm{~km} \mathrm{~h}^{-1}$ and $88,000 \mathrm{~kW} \mathrm{~m}^{-1}$, respectively, and spot fires ignited as far as $33 \mathrm{~km}$ from the head of the fire. Only a few relatively small ( $<200$ ha) 1-2-year-old PB areas were in the path of the four major Black Saturday fires, and not all of them presented decreased fire severity, but satellite imagery showed patterns of diminished fire severity for a few kilometres downwind of the PB areas [3, 35]. Remotely sensed burn severity using systematic sampling (500-m grid) was used to model the likelihoods of surface and crown fire in the Black Saturday fires as a function of fuel age and fire danger classification [36]. Surface fire probability was high for time since fire $<10$ years and $<6$ years, respectively, under Low and Moderate fire danger, but insignificant under Catastrophic danger.

\section{USA}

Recent studies in the USA evaluating the impact of PB on wildfire severity have sampled treated and adjacent untreated plots, as paired analysis in an attempt to neutralize confounding effects of variable topography and weather. The 2006 Tripod Complex Fires in Washington burned about 70,000 ha of semi-arid mixed conifer forest under extreme weather in complex terrain. These fires were influenced by numerous areas where fuels had been reduced within the previous 6 years. Crown scorch volume and burn severity were all significantly lower in thin-PB areas in comparison with thinned and untreated areas, and the differences were especially marked for larger $(>20 \mathrm{~cm} \mathrm{dbh})$ trees [37]. Three years after the wildfire, cumulative tree mortality in thin-PB units was $43 \%$, whereas it reached 64 and $78 \%$ in thin-only and untreated areas, respectively; infestation of the live trees by bark beetles was also lower in the thin-PB units [38].

Convincing evidence was found of substantially decreased fire severity in areas thinned and prescribed burnt up to 9 years before wildfire in Eastern and Southern California conifer forests, with the authors stating that "quantitative assessments of fuel treatment effects on fire severity in frequent-fire forest types hardly merit further effort' [39•]. The analysis included 12 wildfires that occurred between 2005 and 2011 (varying from 112 to 15,095 ha in size) in distinct landscapes and weather scenarios (although generally dry and warm) that typically spread at $1-2 \mathrm{~km} \mathrm{~h}^{-1}$ under moderate to high winds. Metrics of burn severity in trees were much higher in untreated stands than in their treated counterparts; fire severity declined with distance from the treatment edge and crowning seldom extended beyond $70 \mathrm{~m}$ of the edge. The same set of fires was used to compare short-term (2 years after fire) resiliency between treated and untreated plots [40]. Live-tree cover, among other ecological attributes, was higher in treated stands, which changed less due to wildfire than the untreated stands.

The 2011 Wallow Fire burned $2165 \mathrm{~km}^{2}$ and was the largest fire ever recorded in Arizona. The density of fire-killed trees was lower in treated stands by a factor of six, and highseverity patch size was significantly smaller in a study conducted on sites that had burned on fast spread days under 6 to $15 \%$ minimum relative humidity and 38 to $68 \mathrm{~km} \mathrm{~h}^{-1}$ maximum wind speeds [41]. Post-fire resilience was enhanced by fuel reduction treatments; surviving tree density and size in these areas was within natural variability and closer to reference conditions.

Another series of studies used the differenced normalized burn ratio (dNBR) or its relative version (RdNBR) calculated from pre- and post-burn Landsat Thematic Mapper (TM) imagery to retrospectively assess and map burn severity. For three fires in the Western USA (of which two approached or exceeded 20,000 ha), remotely sensed fire severity was combined with geospatial datasets and sequential autoregression to deal with implicit spatial autocorrelation [42]. PB decreased burn severity in conjunction with mechanical thinning, only when thinning was present or irrespective of thinning. The Tripod Complex Fires were revisited using a similar approach [43]. Results showed poor correlation between fire severity and treatment age and size, but fuel treatments that included PB reduced burn severity even under extreme fire weather; model explanation of burn severity increased from 76 to $93 \%$ with the inclusion of treatment as an independent variable.

In another case study in dry coniferous forest in Southern Idaho where PB had been used within the previous 3 years, 
wildfire severity was significantly higher in untreated buffers encircling the treated patches [44]. The authors modelled potential wildfire severity in the untreated buffers from pre-fire vegetative and topographic variables, applied the model to treated units and obtained higher proportions of low, moderate and high burn severity and lower proportion in the unburned low class had PB not been implemented.

Cochrane et al. [45•*] developed a method that allows estimating spatially explicit probabilities of burning in the presence of fuel treatments. Wildfire growth is simulated with FARSITE and calibrated to match the observed fire expansion. Calculation and mapping of the change in burn probability caused by the treatments is enabled by comparison with simulations for the same landscape, hypothetically untreated. The methodology was exercised in 14 wildfires ranging in size from 365 to 186,878 ha that occurred between 2002 and 2010 in nine US states; the percentage of treated landscape varied from 5.3 to $57.1 \%$. The study did not individualize PB from other treatments. On average, fuel treatments decreased individual fire size by $7.2 \%$, and the observed change was higher when higher fractions of the landscape were treated. However, the variation in fire size change was high (-64 to $46 \%$ ), including three wildfires for which the treatments increased wildfire size. For each hectare treated, burn probability was changed (either increasing or decreasing) on 5 ha. Nonetheless, where fire risk increased, the corresponding probability was generally low. The reduction in area burned was primarily a function of the likelihood of long-range spotting, which in turn is mostly a function of crown fire activity. The authors conclude that because of the variety of factors involved, it is impossible to absolutely measure fuel treatment effectiveness at the landscape scale.

\section{Landscape- to Regional-Scale Studies}

Analysis at spatial and time scales larger than individual wildfires is useful for evaluating the effectiveness of established PB programmes. Most of the available studies come from Australia, possibly reflecting both the widespread and controversial usage of PB [46-48].

In the dry eucalypt forests of the Sydney region (40, $090 \mathrm{~km}^{2}$ ), the likelihood of a wildfire encountering a PB patch younger than 6 years was $22 \%$ (based on data from 1991 to 2000), about half of the probability of a wildfire-wildfire interaction [49]. Two thirds of the PB-wildfire interactions resulted in wildfire containment at the edge $(18 \%)$ or within the patch (44\%). The burn leverage [50] effect of PB (or its return for effort) quantifies how much unplanned burned area is reduced per unit area of $\mathrm{PB}$ or, more generally, the unit reduction in fire area produced by one unit of antecedent fire. Leverage is expected to increase with fire incidence, the average fraction of the landscape that burns every year [51•]. In the Sydney region, $\mathrm{PB}$ accounted for $13 \%$ of the total burned area in
30 years, with a leverage of 0.33 (controlled for annual variation in fire weather), i.e. three prescribed burnt ha were required to reduce wildfire area by 1 ha [52].

Boer et al. [53] provided the most comprehensive analysis to date of the effects of PB on wildfire activity. The study was conducted in the $9300-\mathrm{km}^{2}$ Warren Region in the high-rainfall (700-1400 mm year ${ }^{-1}$ ) zone of South-Western Australia, which is predominantly open eucalypt forest, using data from 1953 to 2004. PB accounted for $82 \%$ of the annual area burnt in the region, with an annual treatment effort of 7-9\% of the landscape, which is substantially higher than in South-Eastern Australia. The effect of PB on wildfire activity was negligible beyond 6-years post-treatment, which is consistent with fuel dynamics [17] and observed fire behaviour [31•]. Annual PB area explained $71 \%$ of wildfire area variability - both averaged over 6-year intervals - with a leverage of 0.25 , similar to South-Eastern Australia. Over the study period, the incidence of large fires (100 to $10,000 \mathrm{ha}$ ) responded to variation in PB effort, with increases following decreases in the amount of area treated. Interestingly, PB effectiveness in decreasing wildfire area was stronger in years during which wildfire extent was uncommonly high. Higher connectivity between old ( $>6$ years) fuel patches and lower perimeter-area-ratio of those patches (i.e. lower edge complexity) tended to increase wildfire extent. In February 2015, the region was affected by the lightning-ignited Northcliffe Fire, the largest since 1961, which burned 97,000 ha through $>15$-year-old fuels in tall eucalypt forest but was hindered by 3year-old fuels in its southerly spread; last rainfall had occurred more than 2 months before the fire; daily minimum dead fine fuel moisture contents and maximum wind speeds reached $6-7 \%$ and $33-46 \mathrm{~km} \mathrm{~h}^{-1}$, and fire danger classification was high to very high (L. McCaw, personal correspondence).

The Osceola National Forest in North Central Florida (93, 000 ha) has a frequent (2-5 years) PB programme with an approximate annual target of $14 \%$ of its pine forest. For the 1998-2008 period, analysis of Landsat imagery showed PB reduced the likelihood of high burn severity up to 5 years posttreatment [54].

Butry [55] used an econometric approach through propensity score matching models to quantify the returns of fire management (PB and fire suppression) in the St. Johns River Water Management District in Northeast Florida $\left(1700 \mathrm{~km}^{2}\right)$ from 1996 to 2001. The author quantified the effect of PB area on fireline intensity (inferred from flame length recorded during fire control operations) weighted by unit area and found that 'a $1 \%$ increase in prescribed fire acres yields a $0.0138 \%$ decrease in wildfire intensity-acres' and that 'for every $\$ 1$ spent on prescribed fire treatments, $\$ 1.53$ in wildfire damage was avoided'. The impact of PB on wildfire extent and intensity was deemed to persist for 3 years since treatment and was significant only where fire suppression response time was 
not, suggesting that $\mathrm{PB}$ and fire fighting are alternatives rather than complements.

Price et al. [51 ${ }^{\circ}$ assessed burn leverage in the Sequoia and Kings Canyon National Park (74,100 ha) in Central California using data from 1945 to 2011. Fire management changed in 1968 to accommodate wildland fire use (see next section). Post-1968 annual burned area was low (1\%, of which half was PB) with nil leverage. The result was probably conditioned by different fire suppression responses in years of below- and above-average fire activity and spatially nonrandom fire management.

A fire management programme that restores/adapts traditional aboriginal burning practices has been in place since 2005 in the savannah woodlands of Western Arnhem Land (Northern Australia, 24,000 $\mathrm{km}^{2}$ ), to decrease the surface burned by late dry-season fires and the associated fire severity and carbon emissions [10]. Early dry-season PB succeeded in decreasing the annual burnt fraction of the landscape from 38 to $30 \%$, especially of late dry-season fires ( 29 to $12.5 \%$ ), as assessed from Landsat imagery for the period of 1990 to 2009, with a burn leverage of 0.9 [56], and cut carbon emissions by $38 \%$ [10]. In the Arnhem Land $\left(56,000 \mathrm{~km}^{2}\right)$, there is a $92 \%$ probability of very large (110 to $\left.2300 \mathrm{~km}^{2}\right)$ fires stopping at the edge of early dry-season fires [57]. In the same region, the probability of severe fire (i.e. high crown scorch height) increased with time since fire, from 3 to $8 \%$ and from 21 to $43 \%$, at 1 and 5 years after burning, for early dry- and late dryseason fires, respectively.

PB is a relevant component of fire management in Kruger National Park $\left(18,000 \mathrm{~km}^{2}\right.$ in size) in North-Eastern South Africa. Fuels, as in Northern Australia, are grass dominated but leverage based on records from 1957 to 2012 is nonexistent [51•], which was credited to rainfall patterns, herbivore pressure and rotational burning whereby new and previous PB patches seldom 'meet' for at least 3 years.

Spinifex grasslands of the Great and Little Sandy Desert bioregions of Western Australia $\left(46,000 \mathrm{~km}^{2}\right)$ burn at an annual average rate of $9.7 \%$ based on satellite-based mapping for the period 1999 to 2010 [58]. Mean and median fire sizes are lower by one order of magnitude under the aboriginal burning regime versus the lightning regime; less variation in fire size and a smaller than expected number of fires $>100$ ha also characterize the aboriginal regime. Using the same database, a leverage value of 0.34 was obtained, not distinguishing between the two causes of fire [51•].

PB comprised 4.6 to $32.4 \%$ of the total surface burned over 33 to 37 years in 10 protected areas (totalizing 0.73 million ha) of fynbos, the mediterranean-type shrublands of South Africa's southeast corner [59]. Fire frequency analysis indicated a weak effect of time since fire on burn probability, with median fire return intervals of 10 to 21 years. The influence of PB on overall fire frequency was judged irrelevant [7, 59].

\section{Wildfires as Fuel Treatments}

The spatial extent of PB treatments is critical regarding the disruption of wildfire rate of growth and the consequent decrease in area burned, as shown by the previously discussed leverage studies. Comparison of wildfire size and severity on areas where fuel accumulation has reached pre-burn levels with those still recovering provides useful insights on the effectiveness of large-scale PB, as a wildfire can be thought of as an unplanned treatment from the point of view of fuel management [45••]. An obvious caveat of this approach is that PB and wildfire typically occur under different weather and drought conditions and have distinct impacts on vegetation. Consequently, PB and wildfire are likely to differ in regards to fuel consumption, fuel creation (e.g. transition of live to dead fuels) and post-fire fuel recovery rates.

A few studies in the USA have recently addressed how fire size or fire severity are affected by previous wildfires, mostly in wilderness areas and national parks with 'wildland fire use' programmes that began in the early 1970s (i.e. where naturally ignited fires are allowed to burn for resource benefits if they do not pose a threat to assets and communities [60,61]). One such area is the Yosemite National Park (located in the Sierra Nevada mountains of Central California), where fires are smaller, less of the landscape is burned by high-severity fire and high-severity patches are smaller in comparison with other Californian regions (Southern Cascades and the Modoc Plateau) that are under a different fire management policy [60]. Because of the length of time, the wildland fire use policy has been in effect in Yosemite, free-burning fires in mixed conifer forest types are now self-limiting: both fire size and fire severity are inhibited by recently burned areas, which under non-extreme weather conditions are very effective barriers to fire spread for up to 8 years after fire [62]. Also, consecutive overlapping fires tended to burn with similar severity in the Illilouette Creek basin of Yosemite, with a 9-year old fuel age threshold for increased fire severity [61]. The 2013 Rim Fire in Yosemite burned 100,000 ha, of which 30, 000 ha or approximately a third occurred inside the park, where irrespective of other factors, burn severity was moderate to high ( $55 \%$ of the number of field plots) in days with strong convective activity but generally low under similar weather conditions when time since fire was $<14$ years [63]. In three wilderness areas in Montana and Idaho (totalling about 5 million ha), fire size increased with time since fire, especially after 6 years, and overlapping between consecutive fires was more likely in large fire years but nevertheless was minimal [64]. Growth of the Tripod Complex Fires was bounded by fires that had occurred 5 to 12 years before [43].

A satellite-based assessment of 117 fires occurring between 1994 and 2008 in two wilderness areas, one in Western New Mexico $\left(3190 \mathrm{~km}^{2}\right)$ and the other in Central Idaho $\left(9574 \mathrm{~km}^{2}\right)$, revealed lower fire severity in areas experiencing 
at least two fires versus areas burnt only once, an effect that persisted for approximately 22 years after fire [65]. Also, burn severity tended to increase with time since fire, as well as with the severity of the preceding fire, possibly because of forest conversion to shrubland [61]. In these two areas, plus one in Western Montana $\left(10,331 \mathrm{~km}^{2}\right)$ and another in North Central Idaho $\left(5471 \mathrm{~km}^{2}\right)$, an assessment was made of whether, and to what extent, antecedent fire activity impeded wildfire spread, using fire growth mapping and accounting for the effect of weather [66 ${ }^{\circ}$. The study identified 1038 fires in the period from 1972 to 2012, of which $60 \%$ interacted with subsequent fires. Wildfires interrupted the expansion of subsequent fires for 6 and 14 years, respectively, in the driest and wetter areas, an effect that declined with time and was moderated by severe fire weather.

Haire et al. [67] analysed the distribution of fire sizes for the years 1984 to 2007 in the Western USA (Southwest, Sierra Nevada and Northern Rockies regions). In contrast to the aforementioned studies, no evidence was found of a decrease in the relative importance of large fires across the wilderness gradient, except in the Southwest. The authors suggest that a longer time frame is needed to reach any robust conclusions.

A particular environment characterized by strong and dry autumn winds drives most large fires in Southern California [68], limiting the usefulness of fuel-break networks to wildfire control operations [69]. Recently burned chaparral areas typically reburn under those conditions. Twenty-five percent of the area burned by the 2007 fires corresponded to fuel ages up to 5 years, including overlap with the large fires of 2003 [70]. This, and the fact that little fire-on-fire interaction occurs because only $2 \%$ of the landscape burns annually, explains why leverage is zero in Southern California [71]. The fuel age dependency of fire spread is also short-lived in other mediterranean climate shrub-dominated landscapes, namely in South Africa, previously mentioned [59], and in Portugal [72]. In the latter case (with a land mass of $89,000 \mathrm{~km}^{2}$ ), the median firefree interval for areas that burned twice or more during the period 1975 to 2008 was 13 to 19 years, depending on region; larger fires, or fires occurring under severe fire weather conditions, were slightly less constrained by young fuels but on the other hand, selected increasingly older vegetation. Burn leverage in Portugal (0.9) is substantially higher than expected from the $\%$ annual area burnt, which might be related with non-random spatial incidence of fire due to topographic breaks and vegetation fragmentation [51•].

The likelihood that past fire mitigates future fire spread and intensity ultimately depends on the coincidence and interaction between available fuel - a combined function of burnable biomass and its dryness and weather conducive to fire spread and ignition density [73]. The relative role of fuel and climateweather changes along the productivity gradient. Fire activity is more dependent on suitable weather and drought conditions where fuels are plentiful and recover quickly after disturbance, whereas in less productive regions, it is regulated by fuel amount and connectivity [74]. A study by O'Donnell et al. [75] provides a vivid example of a fuel-limited fire regime: semi-arid mediterranean shrublands and woodlands in the 1.5 million ha Lake Johnston region of South-Western Australia, that rarely burns within 20 years of the last fire, regardless of fire size and even under extreme fire weather conditions.

\section{Conclusions}

PB effectiveness is dependent on treatment longevity, effort (i.e. \% area treated), spatial patterns and location in relation to subsequent wildfires, plus vegetation type, topography and weather. The criteria and metrics used to assess the effectiveness of PB as a fuel treatment can vary depending on its objectives, which broadly range from protecting human life and property to mitigating against the negative environmental impacts of wildfire.

The area burned by wildfire is often the main criteria used in assessing the success of fire management. PB treatment presumably decreases the spread rate and intensity of subsequent wildfire occurrences. However, in more productive regions, benefits to fire suppression that would result in smaller fires and overall decreases in the extent of wildfires may be irrelevant under extreme fire weather conditions beyond a few years after treatment (e.g. 5-6 years in forest). Then, it is not surprising that current evidence suggests that the influence of PB on unplanned fire extent is weak to non-existent unless a substantial part (5-10\%) of the landscape is treated annually. At best, as indicated by leverage studies, $\mathrm{PB}$ will replace wildfire area. Given the relatively low return for effort of $\mathrm{PB}$, it is crucial to carefully consider its spatial patterns [22], namely by using adequate optimization methods [76]. Insufficient resources and other constraints can easily preclude treatment of the required fraction of the landscape for PB to have a tangible effect on wildfire extent. Under these circumstances, priority should be given to the strategic placement of treatments in the vicinity of areas of perceived high value like wildland-urban interfaces $[49,77]$. Because of the difficulty in carrying out fuel treatments at the required scale, a flexible response to unplanned fire has been recently proposed as a fire management option for the Mediterranean Basin [6, 78, 79].

The mitigating effect of PB on fire severity both at the stand- and landscape scale is seemingly settled, especially where the subject has been addressed more thoroughly and through complementary approaches, for example in the conifer forests of the Southern and Western USA. This has been made possible by methodological and analytical advances, including the consideration of wildfire as a surrogate fuel treatment. On-the-ground evaluation of fire severity modification is now ordinarily based on paired treated-untreated plots to minimize the influence of weather and topography 
variability in confounding the resultant interpretations. Burn severity classification and mapping from satellite imagery, assisted by adequate statistical analysis techniques, is more and more used to study the effects of PB at large spatial scales and brought obvious improvements in relation to the sampling and inference limitations that characterized previous studies.

In spite of the advances made in the past few years, the evaluation of $\mathrm{PB}$ effectiveness will remain a challenge in most ecosystems, both from the scientist and decision-maker perspectives, especially as climate change will facilitate more extreme fire events. As mentioned by McCaw [3], ‘... no single line of evidence is likely to be sufficiently robust or free from bias to adequately quantify the effectiveness of fuel reduction burning. Bias may be introduced by imperfect knowledge of fire behaviour, and by the opinions of the investigators themselves. An integrated approach that draws on a broad range of indicators offers the best way forward'. Assessing the decrease in high-intensity (or high-severity) fire in treated areas is emerging as a more meaningful and realistic objective than quantifying the putative decrease in area burned caused by PB. Future research should target more systematic collection of fire behaviour data during on-going wildfires in $\mathrm{PB}$ areas, especially in shrublands and other open vegetation types where the absence of tall trees precludes the analysis of changes in fire severity.

Acknowledgments This paper is a contribution to the MedWildFireLab network 'Global Change Impacts on Wildland Fire Behaviour and Uses in Mediterranean Forest Ecosystems, towards a «wall less» Mediterranean Wildland Fire Laboratory' within the FP7 FORESTERRA Era-Net. Comments by Marty Alexander and Dale Wade improved the paper and are appreciated, as well as the Northcliffe Fire information supplied by Lachlan McCaw.

\section{Compliance with Ethics Guidelines}

Conflict of Interests Dr. Fernandes states that he has no conflicts of interest to declare.

Human and Animal Rights and Informed Consent This article contains no studies with human or animal subjects performed by the author.

\section{References}

Papers of particular interest, published recently, have been highlighted as:

- Of importance

•- Of great importance

1. Collins RD, de Neufville R, Claro J, Oliveira T, Pacheco AP. Forest fire management to avoid unintended consequences: a case study of Portugal using system dynamics. J Environ Manage. 2013;130:1-9.

2. Fernandes PM, Botelho HS. A review of prescribed burning effectiveness in fire hazard reduction. Int J Wildland Fire. 2003;12:11728.
3. McCaw WL. Managing forest fuels using prescribed fire- a perspective from southern Australia. For Ecol Manag. 2013;294:21724.

4. Scott AC, Bowman DMJS, Bond WJ, Pyne SJ, Alexander ME. Fire on Earth: an introduction. John Wiley \& Sons; 2014.

5. Waldrop TA, Goodrick SL. Introduction to prescribed fires in Southern ecosystems [Internet]. U.S. Department of Agriculture Forest Service, Southern Research Station. Asheville, NC; 2012 [cited 2015 Feb 4]. Available from: http://www.treesearch.fs.fed. us/pubs/41316

6. Fernandes PM, Davies GM, Ascoli D, Fernández C, Moreira F, Rigolot E, et al. Prescribed burning in southern Europe: developing fire management in a dynamic landscape. Front Ecol Environ. 2013;11:e4-14.

7. Van Wilgen BW. Fire management in species-rich Cape fynbos shrublands. Front Ecol Environ. 2013;11:e35-44.

8. Ryan KC, Knapp EE, Varner JM. Prescribed fire in North American forests and woodlands: history, current practice, and challenges. Front Ecol Environ. 2013;11:e15-24.

9. Burrows N, McCaw L. Prescribed burning in southwestern Australian forests. Front Ecol Environ. 2013;11:e25-34.

10. Russell-Smith J, Cook GD, Cooke PM, Edwards AC, Lendrum M, Meyer C, et al. Managing fire regimes in north Australian savannas: applying Aboriginal approaches to contemporary global problems. Front Ecol Environ. 2013;11:e55-63.

11. Martinson EJ, Omi PN. Fuel treatments and fire severity: a metaanalysis [Internet]. 2013 [cited 2015 Feb 2]. Available from: http:// www.treesearch.fs.fed.us/pubs/43632

12. Hollis JJ, Matthews S, Anderson WR, Cruz MG, Burrows ND. Behind the flaming zone: predicting woody fuel consumption in eucalypt forest fires in southern Australia. For Ecol Manag. 2011;261:2049-67.

13. Reid AM, Robertson KM, Hmielowski TL. Predicting litter and live herb fuel consumption during prescribed fires in native and old-field upland pine communities of the southeastern United States. Can J For Res. 2012;42:1611-22.

14. Fernandes PM, Loureiro C. Fine fuels consumption and CO2 emissions from surface fire experiments in maritime pine stands in northern Portugal. For Ecol Manag. 2013;291:344-56.

15. Wright CS. Models for predicting fuel consumption in sagebrushdominated ecosystems. Rangel Ecol Manag. 2013;66:254-66.

16. Ottmar RD. Wildland fire emissions, carbon, and climate: modeling fuel consumption. For Ecol Manag. 2014;317:41-50.

17. Gould JS, Lachlan McCaw W, Phillip CN. Quantifying fine fuel dynamics and structure in dry eucalypt forest (Eucalyptus marginata) in Western Australia for fire management. For Ecol Manag. 2011;262:531-46.

18. Fernandes PM. Silvicultura preventiva e gestão de combustíveis: opções e optimização. In: Santos Pereira J, Cardoso Pereira JM, Rego F, Silva J, Silva T, editors. Incêndios Florestais em Portugal. Caracterização, Impactes e Previsão. Lisboa: Portugal: ISA Press; 2006. p. 327-54.

19. Cruz MG, Alexander ME. Assessing crown fire potential in coniferous forests of western North America: a critique of current approaches and recent simulation studies. Int $\mathrm{J}$ Wildland Fire. 2010;19:377-98.

20. Cruz MG, Alexander ME, Dam JE. Using modeled surface and crown fire behavior characteristics to evaluate fuel treatment effectiveness: a caution. For Sci. 2014;60:1000-4.

21. Fernandes PM. Examining fuel treatment longevity through experimental and simulated surface fire behaviour: a maritime pine case study. Can J For Res. 2009;39:2529-35.

22. Price $\mathrm{O}$. The drivers of effectiveness of prescribed fire treatment. For Sci. 2012;606-17. 
23. Cruz MG, Alexander ME. Uncertainty associated with model predictions of surface and crown fire rates of spread. Environ Model Softw. 2013;47:16-28.

24. Fernandes P. Upscaling the estimation of surface-fire rate of spread in maritime pine (Pinus pinaster Ait.) forest. IForest Biogeosci For. 2014;7:123-5.

25. Cruz MG, McCaw WL, Anderson WR, Gould JS. Fire behaviour modelling in semi-arid mallee-heath shrublands of southern Australia. Environ Model Softw. 2013;40:21-34.

26. Davies GM, Legg CJ, Smith AA, MacDonald AJ. Rate of spread of fires in Calluna vulgaris-dominated moorlands. J Appl Ecol. 2009;46:1054-63.

27. Anderson W, Cruz MG, Fernandes PM, McCaw L, Vega JA, Bradstock R, et al. A generic, empirical-based model for predicting rate of fire spread in shrublands. Int. J. Wildland Fire. [Internet]. 2015 [cited 2015 Feb 4]; Available from: http://www.publish.csiro. $\mathrm{au} /$ ?paper $=\mathrm{WF} 14130$.

28. Fernandes PM, Botelho HS, Rego FC, Loureiro C. Empirical modelling of surface fire behaviour in maritime pine stands. Int $\mathrm{J}$ Wildland Fire. 2009;18:698-710.

29. Vega JA. Selvicultura preventiva de incendios forestales en formaciones de matorral del noroeste de España: análisis comparativa de la eficacia de los tratamientos y de los efectos edáficos producidos. Lourizán: CIF Lourizán; 2010.

30. Fernandes PM, Loureiro C, Botelho H. PiroPinus: a spreadsheet application to guide prescribed burning operations in maritime pine forest. Comput Electron Agric. 2012;81:58-61.

31. McCaw L, Gould JS, Cheney P, Ellis PFM, Anderson WR. Changes in behaviour of fire in dry eucalypt forest as fuel increases with age. For Ecol Manag. 2012;271:170-81

This study experimentally assessed fire behaviour characteristics as a function of fuel age and fuel structure.

32. Cheney NP, Gould JS, McCaw WL, Anderson WR. Predicting fire behaviour in dry eucalypt forest in southern Australia. For Ecol Manag. 2012;280:120-31.

33. Cheney NP. Fire behaviour during the Pickering Brook wildfire, January 2005 (Perth Hills Fires 71-80). Conserv Sci West Aust. 2010;7:451-68.

34. Cruz MG, Sullivan AL, Gould JS, Sims NC, Bannister AJ, Hollis JJ, et al. Anatomy of a catastrophic wildfire: the Black Saturday Kilmore East fire in Victoria. Australia For Ecol Manag. 2012;284: 269-85.

35. McCaw WL. Report on the effect of fuel reduction burning on the behaviour and severity of the Victorian bushfires of 7 February 2009. A report prepared for the 2009 Victorian bushfires Royal Commission. 2009;p.22.

36. Price OF, Bradstock RA. The efficacy of fuel treatment in mitigating property loss during wildfires: insights from analysis of the severity of the catastrophic fires in 2009 in Victoria. Australia J Environ Manage. 2012;113:146-57.

37. Prichard SJ, Peterson DL, Jacobson K. Fuel treatments reduce the severity of wildfire effects in dry mixed conifer forest, Washington. USA Can J For Res. 2010;40:1615-26.

38. Prichard SJ, Kennedy MC. Fuel treatment effects on tree mortality following wildfire in dry mixed conifer forests, Washington State. USA Int J Wildland Fire. 2012;21:1004-13.

39. Safford HD, Stevens JT, Merriam K, Meyer MD, Latimer AM. Fuel treatment effectiveness in California yellow pine and mixed conifer forests. For Ecol Manag. 2012;274:17-28

This study compared tree mortality and fire severity metrics between treated (thin and burn) and untreated paired sites exposed to wildfires in the conifer forests of California.

40. Stevens JT, Safford HD, Latimer AM. Wildfire-contingent effects of fuel treatments can promote ecological resilience in seasonally dry conifer forests. Can J For Res. 2014;44:843-54.
41. Waltz AEM, Stoddard MT, Kalies EL, Springer JD, Huffman DW, Meador AS. Effectiveness of fuel reduction treatments: assessing metrics of forest resiliency and wildfire severity after the Wallow Fire. AZ For Ecol Manag. 2014;334:43-52.

42. Wimberly MC, Cochrane MA, Baer AD, Pabst K. Assessing fuel treatment effectiveness using satellite imagery and spatial statistics. Ecol Appl. 2009;19:1377-84.

43. Prichard SJ, Kennedy MC. Fuel treatments and landform modify landscape patterns of burn severity in an extreme fire event. Ecol Appl. 2014;24:571-90.

44. Arkle RS, Pilliod DS, Welty JL. Pattern and process of prescribed fires influence effectiveness at reducing wildfire severity in dry coniferous forests. For Ecol Manag. 2012;276:174-84.

45.• Cochrane MA, Moran CJ, Wimberly MC, Baer AD, Finney MA, Beckendorf KL, et al. Estimation of wildfire size and risk changes due to fuels treatments. Int J Wildland Fire. 2012;21:357-67. Burn probability in fuel-treated vs. untreated landscapes is assessed using calibrated fire growth simulation.

46. Attiwill PM, Adams MA. Mega-fires, inquiries and politics in the eucalypt forests of Victoria, south-eastern Australia. For Ecol Manag. 2013;294:45-53.

47. Clode D, Elgar MA. Fighting Fire with Fire: Does a Policy of Broad-Scale Prescribed Burning Improve Community Safety? Soc Nat Resour. 2014;27:1192-9.

48. Moritz MA, Batllori E, Bradstock RA, Gill AM, Handmer J, Hessburg PF, et al. Learning to coexist with wildfire. Nature. 2014;515:58-66.

49. Price OF, Bradstock RA. The effect of fuel age on the spread of fire in sclerophyll forest in the Sydney region of Australia. Int $\mathrm{J}$ Wildland Fire. 2010;19:35-45.

50. Loehle C. Applying landscape principles to fire hazard reduction. For Ecol Manag. 2004;198:261-7.

51. Price O, Pausas J, Govender N, Flannigan M, Fernandes P, Brooks M, Bird RB. Global patterns in fire leverage: the response of annual area burnt to previous fire. Int J Wildland Fire. [Internet]. 2015 [cited 2015 Feb 5]; Available from: http://www.publish.csiro.au/ view/journals/dsp_journals_pip_abstract_Scholar1.cfm?nid= 114\&pip=WF14034. Burn leverage (the dependence of burned area on previous burned area) in several regions of the world is analysed individually and jointly.

52. Price OF, Bradstock RA. Quantifying the influence of fuel age and weather on the annual extent of unplanned fires in the Sydney region of Australia. Int J Wildland Fire. 2011;20:142-51.

53. Boer MM, Sadler RJ, Wittkuhn RS, McCaw L, Grierson PF. Longterm impacts of prescribed burning on regional extent and incidence of wildfires - evidence from 50 years of active fire management in SW Australian forests. For Ecol Manag. 2009;259:132-42.

54. Malone SL, Kobziar LN, Staudhammer CL, Abd-Elrahman A. Modeling relationships among 217 fires using remote sensing of burn severity in southern pine forests. Remote Sens. 2011;3:200528.

55. Butry DT. Fighting fire with fire: estimating the efficacy of wildfire mitigation programs using propensity scores. Environ Ecol Stat. 2009;16:291-319.

56. Price OF, Russell-Smith J, Watt F. The influence of prescribed fire on the extent of wildfire in savanna landscapes of western Arnhem Land, Australia. Int J Wildland Fire. 2012;21:297-305.

57. Price OF, Borah R, Maier SW. Role of weather and fuel in stopping fire spread in tropical savannas. Austral Ecol. 2014;39:135-44.

58. Bliege Bird R, Codding BF, Kauhanen PG, Bird DW. Aboriginal hunting buffers climate-driven fire-size variability in Australia's spinifex grasslands. Proc Natl Acad Sci U S A. 2012;109:1028792.

59. Van Wilgen BW, Forsyth GG, De Klerk H, Das S, Khuluse S, Schmitz P. Fire management in Mediterranean-climate shrublands: 
a case study from the Cape fynbos. South Africa J Appl Ecol. 2010;47:631-8.

60. Miller JD, Collins BM, Lutz JA, Stephens SL, van Wagtendonk JW, Yasuda DA. Differences in wildfires among ecoregions and land management agencies in the Sierra Nevada region, California, USA. Ecosphere. 2012;3:art80.

61. Van Wagtendonk JW, van Wagtendonk KA, Thode AE. Factors associated with the severity of intersecting fires in Yosemite National Park, California. USA Fire Ecol. 2012;7:11-31.

62. Collins BM, Miller JD, Thode AE, Kelly M, Van Wagtendonk JW, Stephens SL. Interactions among wildland fires in a longestablished Sierra Nevada natural fire area. Ecosystems. 2009;12: 114-28.

63. Lydersen JM, North MP, Collins BM. Severity of an uncharacteristically large wildfire, the Rim Fire, in forests with relatively restored frequent fire regimes. For Ecol Manag. 2014;328:326-34.

64. Teske CC, Seielstad CA, Queen LP. Characterizing fire-on-fire interactions in three large wilderness areas. Fire Ecol. 2012;8:82-106.

65. Parks SA, Miller C, Nelson CR, Holden ZA. Previous fires moderate burn severity of subsequent Wildland fires in two large Western US wilderness areas. Ecosystems. 2014;17:29-42.

66. Parks SA, Holsinger LM, Miller C, Nelson CR. Wildland fire as a self-regulating mechanism: the role of previous burns and weather in limiting fire progression. Ecol Appl. 2015. doi:10.1890/14-1430.

1. The authors examine how previous wildfires constrain fire spread in four large protected areas in the western USA, taking into account time since fire and weather conditions.

67. Haire SL, McGarigal K, Miller C. Wilderness shapes contemporary fire size distributions across landscapes of the western United States. Ecosphere. 2013;4:art15.

68. Moritz MA, Moody TJ, Krawchuk MA, Hughes M, Hall A. Spatial variation in extreme winds predicts large wildfire locations in chaparral ecosystems. Geophys Res Lett. 2010;37:L04801.
69. Syphard AD, Keeley JE, Brennan TJ. Comparing the role of fuel breaks across Southern California National Forests. For Ecol Managem. 2011;261:2038-48.

70. Keeley JE, Safford H, Fotheringham CJ, Franklin J, Moritz M. The 2007 Southern California wildfires: lessons in complexity. J For. 2009;107:287-96.

71. Price OF, Bradstock RA, Keeley JE, Syphard AD. The impact of antecedent fire area on burned area in southern California coastal ecosystems. J Environ Manage. 2012;113: 301-7.

72. Fernandes PM, Loureiro C, Magalhães M, Ferreira P, Fernandes M. Fuel age, weather and burn probability in Portugal. Int $\mathrm{J}$ Wildland Fire. 2012;21:380-4.

73. Bradstock RA. A biogeographic model of fire regimes in Australia: current and future implications. Glob Ecol Biogeogr. 2010;19:14558.

74. Pausas JG, Ribeiro E. The global fire-productivity relationship. Glob Ecol Biogeogr. 2013;22:728-36.

75. O'Donnell AJ, Boer MM, McCaw WL, Grierson PF. Scaledependent thresholds in the dominant controls of wildfire size in semi-arid southwest Australia. Ecosphere. 2014;5: art93-art93.

76. Chung W. Optimizing fuel treatments to reduce Wildland fire risk. Curr For Rep. 2015;1:44-51.

77. Gibbons P, van Bommel L, Gill AM, Cary GJ, Driscoll DA, Bradstock RA, et al. Land management practices associated with house loss in wildfires. PLoS ONE. 2012;7:e29212.

78. Fernandes PM. Fire-smart management of forest landscapes in the Mediterranean basin under global change. Landsc Urban Plan. 2013;110:175-82.

79. Regos A, Aquilué N, Retana J, De Cáceres M, Brotons L. Using unplanned fires to help suppressing future large fires in mediterranean forests. PLoS ONE. 2014;9:e94906. 